\title{
Study of clinical profile of cervical cancer patients: a hospital based study
}

\author{
Preeti Umate, Dhuldev S. Thengal*, Dhundiraj Kurdukar
}

Department of Obstetrics and Gynecology, Dr. V. M. Government Medical College, Solapur, Maharashtra, India

Received: 02 October 2017

Accepted: 11 October 2017

\section{*Correspondence:}

Dr. Dhuldev S. Thengal,

E-mail: vikas_obgy@rediffmail.com

Copyright: (C) the author(s), publisher and licensee Medip Academy. This is an open-access article distributed under the terms of the Creative Commons Attribution Non-Commercial License, which permits unrestricted non-commercial use, distribution, and reproduction in any medium, provided the original work is properly cited.

\begin{abstract}
Background: As a consequence of growing and ageing populations, developing countries are disproportionately affected by the increasing number of cancers. Though the situation in India is gradually improving there still exists a disparity between the availability of quality cancer care. With this view, the present study was planned to undertake in this tertiary care institute to find out symptoms, clinical staging, complications and management of cases of carcinoma of cervix.

Methods: This was a prospective observational study of carcinoma of cervix carried out at a tertiary care hospital catering services to the people of Maharashtra and neighbouring states. A thorough history including presenting complaints, demographic details, educational status and occupational details, details of menstrual and obstetric history along with any significant past history were recorded on a standard proforma.

Results: Most common symptom was per vaginal bleeding which was found in $29(69.04 \%)$. In the present study almost two third of cases i.e. $28(66.6 \%)$ had advanced stage (IIB, III, IV) at the time of admission while the number of cases diagnosed at early stage were only $14(33.3 \%)$. For Wertheim's hysterectomy, most commonly used approach was transperitoneal $08(61.53 \%)$ while $05(38.46 \%)$ were operated by extraperitoneal approach. Pelvic lymph nodes were positive in $03(23.07 \%)$.

Conclusions: A high proportion of patients presented in stages III and IV. This emphasizes the need for early detection of Gynecological cancers in our population. Accordingly, the importance of detection of the pre-clinical stage of the diseases by considering the possibility of initiating cost-effective screening measures needs to be emphasized.
\end{abstract}

Keywords: Cervical cancer, FIGO Staging, Lymph nodes, Wertheim's hysterectomy

\section{INTRODUCTION}

Cancer is an abnormal mass of tissue, the growth of which exceeds and is uncoordinated with that of the normal tissues and persists in the same excessive manner after cessation of the stimuli which evoked the change. ${ }^{1}$

The burden of cancer is distributed unequally between developed and developing countries, with particular cancer types exhibiting different patterns of distribution. As a consequence of growing and ageing populations, developing countries are disproportionately affected by the increasing number of cancers.

Cancer is perhaps the most progressive and devastating disease posing a threat of mortality to the entire world despite significant advances in medical technology for its diagnosis and treatment.

It is estimated that by the year 2020 there will be almost 20 million new cases. Worryingly, it is not only in the number of new cases that will increase but also the 
proportion of new cases from the developing countries like India will also rise to around $70 \% .^{2}$

The most conspicuous feature of the distribution of cancers between the sexes is the male predominance of lung cancer. Among men, the five most common sites of cancers diagnosed in 2012 were lung, prostate, colorectum, stomach and liver. Among women, the five most common sites diagnosed were breast, colorectum, lung, cervix and stomach. Thus, cervical cancer is the fourth most common cancer among women worldwide. ${ }^{3}$ One in every $5^{\text {th }}$ woman in the world suffering from cervical cancer lives in India 4 .

Over $80 \%$ of women with cervical cancer continue to be diagnosed at an advanced stage, which is significantly associated with poor prognosis in developing or less developed countries. ${ }^{5}$

Incidence of carcinoma of cervix, invasive type remains high in our country possibly as:

- Carcinoma cervix is symptomless in early stages

- Procrastination to the initial symptoms like leucorrhoea, post coital bleeding, inter menstrual bleeding leading to negligence by patients.

- Unawareness of symptom complex of carcinoma cervix and its routine screening tests.

- Illiteracy among the majority of population.

- Lack of adequate screening for carcinoma cervix in rural areas.

- Lack of cooperation for mass screening programmes undertaken by research due to lack of cancer consciousness and fear of disease.

Handicaps are further aggravated due to many superstitious beliefs and inability of patient to tell other due to shyness. Financial difficulties also prevent these patients from attending clinic. So, patients come to hospital when distressing symptoms become unbearable and also with advance stage of cancer of cervix.

Though the situation in India is gradually improving there still exists a disparity between the availability of quality cancer care. With this view, the present study was planned to undertake in this tertiary care institute to find out clinical staging, complications and management of cases of carcinoma of cervix attending tertiary care hospital.

Objective of present study was to assess the clinical profile of cervical cancer cases including symptoms, clinical staging, complications and management.

\section{METHODS}

This was a prospective observational study of carcinoma of cervix carried out at a tertiary care hospital catering services to the people of Maharashtra and neighbouring states.
The present study was carried out over a period of 2 years. Ethical committee clearance was obtained before starting the study. Informed consent forms were obtained from all patients. The study included all diagnosed cases of carcinoma of cervix admitted in Gynecology ward of this hospital.

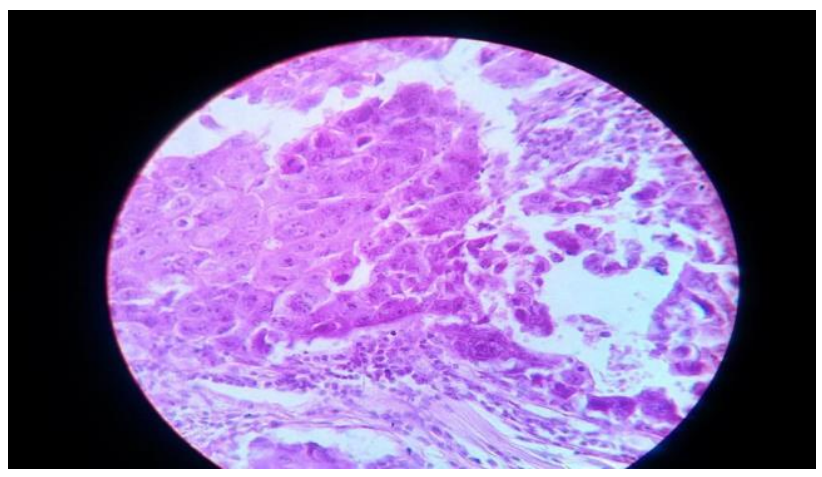

Figure 1: Squamous cell carcinoma.

A thorough history including presenting complaints, demographic details, educational status and occupational details, details of menstrual and obstetric history along with any significant past history were recorded on a standard proforma. History was followed by a thorough general, systemic, gynecological and per rectal examination. Based on these findings, provisional diagnosis was made. The patients were further investigated. Routine investigations were done. HIV testing was also done as per the NACO guidelines. According to the criteria of International Federation of Gynecology and Obstretrics (FIGO), the disease stages were assessed.

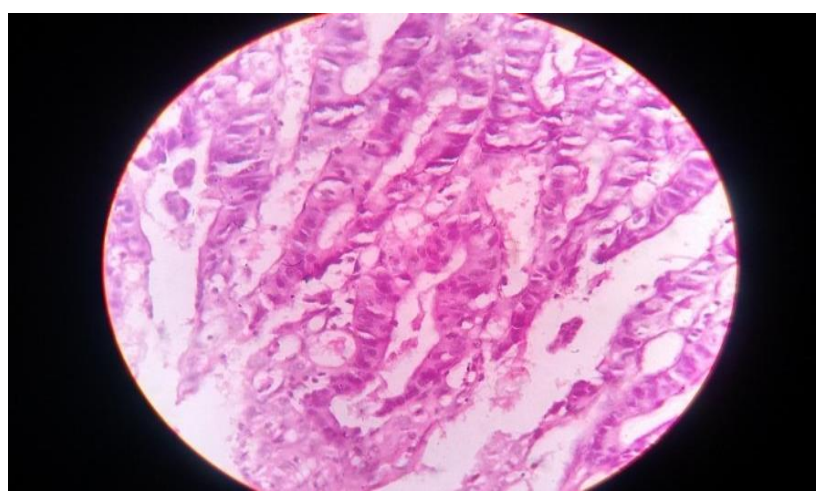

Figure 2: Adenocarcinoma.

The diagnosis of carcinoma of cervix was confirmed on histopathology. Ultrasonography and computed tomography was also done in each case.

Management was done as per the stage of the disease. Early stage cases (stage IB and IIA) were subjected to Wertheim's hysterectomy while cases with advanced stage (stage IIB, III and IV) were advised chemoradiation. Technique of Wertheim's hysterectomy 
(extraperitoneal or transperitoneal) was noted. Intraoperative and postoperative complications were noted. As per the histopathological report of radical hysterectomy specimen and lymph nodes, adjuvant therapy was advised in relevant cases.

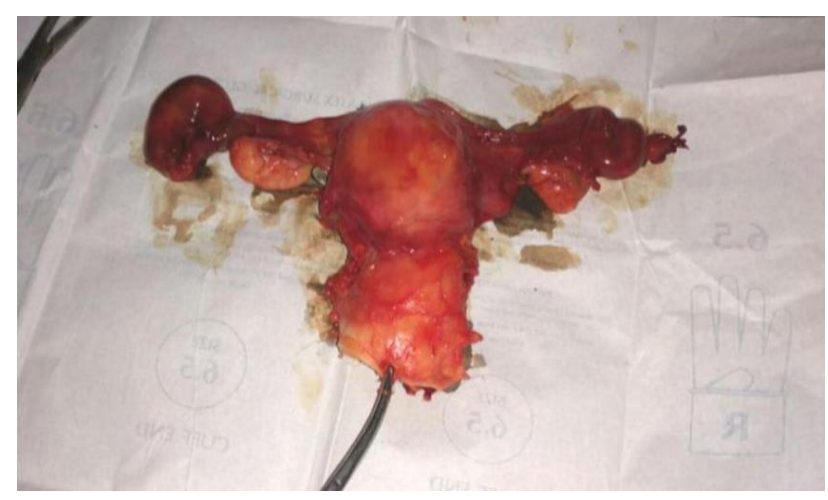

Figure 3: Wertheim's specimen.

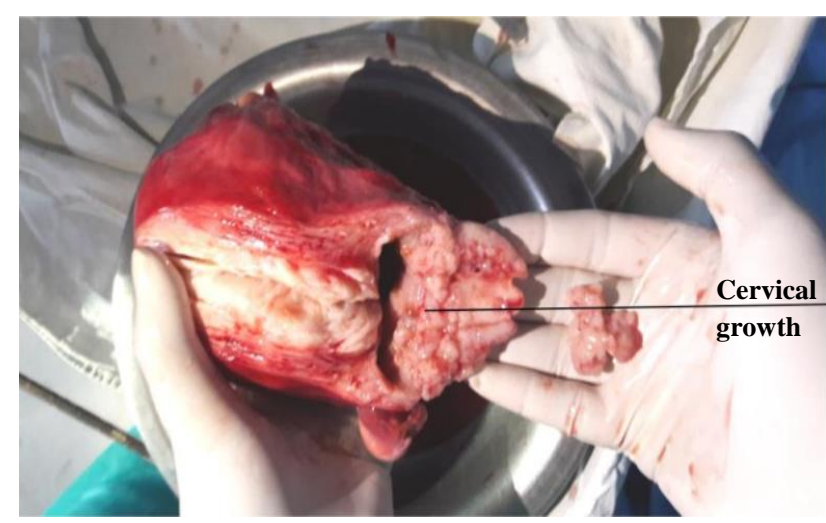

Figure 4: Wertheim's specimen.

\section{Statistical analysis}

Descriptive statistics such as frequency and percentage was used to present the data. Data was analyzed by using SPSS 16.0.

\section{RESULTS}

During the study period, there were 11,270 gynaec O.P.D attendees. Of these, 42 were carcinoma cervix cases.

Table 1: Age distribution.

\begin{tabular}{|lll|}
\hline Age group (years) & No. of cases & Percentage \\
\hline $30-40$ & 05 & 11.90 \\
\hline $41-50$ & 15 & 35.71 \\
\hline $51-60$ & 08 & 19.04 \\
\hline $61-70$ & 12 & 28.57 \\
\hline$>70$ & 02 & 04.76 \\
\hline Total & 42 & 100 \\
\hline
\end{tabular}

Out of 42 , maximum number i.e.15 $(35.71 \%)$ were in the age group of $41-50$ years followed by $12(28.57 \%)$ in the age group of 61-70 years. It showed bimodal peak of incidence. Least number i.e. $02(04.76 \%)$ were in the age group of $>70$ years. Youngest case was 34 years of age (Non- Immunocompromised) and eldest was 81 years old (Table 1).

Most common symptom was per vaginal bleeding which was found in $29(69.04 \%)$ cases. Post coital bleeding, intermenstrual bleeding and post menopausal bleeding were observed as different forms of per vaginal bleeding.

Next common symptom was per vaginal discharge which was found in 14 (33.33\%) cases, of which 08 cases presented with excessive white per vaginal discharge, while 06 complaints of foul smelling discharge. Cachexia was present in $03(07.14 \%)$ cases.

Table 2: Distribution as per symptomatology.

\begin{tabular}{|lll|}
\hline Symptom & $\begin{array}{l}\text { No. of } \\
\text { cases }\end{array}$ & Percentage \\
\hline Post coital bleeding & 06 & 14.28 \\
\hline Intermenstrual bleeding & 10 & 23.80 \\
\hline $\begin{array}{l}\text { Postmenopausal bleeding } \\
\text { Excessive white PV } \\
\text { discharge }\end{array}$ & 13 & 30.95 \\
\hline $\begin{array}{l}\text { Foul smelling discharge } \\
\begin{array}{l}\text { Others - Cachexia, } \\
\text { Backache, Urinary }\end{array}\end{array}$ & 06 & 19.04 \\
Complaints & $03+04+05$ & $\begin{array}{l}07.14+09.52 \\
+11.90\end{array}$ \\
\hline
\end{tabular}

Backache was present in 04 (09.52\%) cases. 05 (11.90\%) cases were having urinary complaints in the form of burning micturation (04 cases) and continuous dribbling of urine (01 case). More than one symptom was present at the time of diagnosis in $13(30.95 \%)$ cases (Table 2$)$.

Table 3: FIGO staging at the time of admission.

\begin{tabular}{|lll|}
\hline Stage & Cases & Percentage \\
\hline IB & 06 & 14.3 \\
\hline IIA & 08 & 19.0 \\
\hline IIB & 10 & 23.8 \\
\hline IIIA & 09 & 21.4 \\
\hline IIIB & 08 & 19.0 \\
\hline IVA & 01 & 02.4 \\
\hline Total & 42 & 100 \\
\hline
\end{tabular}

In this study almost two third of cases i.e. 28 (66.6\%) were having advanced stage (IIB, III, IV) of cervical cancer at the time of diagnosis while only 14 (33.3\%) cases were diagnosed at early stage of cancer (Table 3 ).

The table shows that, staging changed in $01(02.38 \%)$ case from stage IIA to stage IIB after examination under anaesthesia (EUA) (Table 4).

Out of 42 cases, histopathologically majority of cases i.e. $40(95.23 \%)$ had Squamous Cell Carcinoma. Only 2 
(04.76\%) were of Adenocarcinoma. In case of two cases of Adenocarcinoma age at the diagnosis was 44 years and 50 years (Table 5).

Table 4: Clinical staging v/s staging after EUA.

\begin{tabular}{|lll|}
\hline Clinical Staging & Stage & Staging After EUA \\
\hline 06 & IB & 06 \\
\hline 08 & IIA & 07 \\
\hline 10 & IIB & 11 \\
\hline 09 & IIIA & 09 \\
\hline 08 & IIIB & 08 \\
\hline 01 & IVA & 01 \\
\hline 42 & Total & 42 \\
\hline
\end{tabular}

Table 5: Distribution as per histological type.

\begin{tabular}{|lll|}
\hline Histology & Cases & Percentage \\
\hline Squamous cell carcinoma & 40 & 95.23 \\
\hline Adenocarcinoma & 02 & 04.76 \\
\hline Total & 42 & 100 \\
\hline
\end{tabular}

One case was having continuous dribbling of urine at the time of admission. On examination, it was found to be a case of Vesicovaginal fistula. She was stage IVA case.

One case was in uraemia at the time of admission. She was stage IVA case (Table 6).

Table 6: Distribution as per complications at the time of admission.

\begin{tabular}{|lll|}
\hline Complications & Cases & Stage of cancer \\
\hline $\begin{array}{l}\text { VVF (Vesicovaginal } \\
\text { Fistula) }\end{array}$ & $01(02.3 \%)$ & IVA \\
\hline Uraemia & $01(02.3 \%)$ & IVA \\
\hline
\end{tabular}

Out of 42, $13(30.95 \%)$ were of early stage (stage IB + stage IIA) so Wertheim's Hysterectomy was done in these cases. Out of operated, $03(07.14 \%)$ received post operative radiation therapy for positive surgical margins and positive pelvic lymph node. Remaining 29 (69.04\%) were of advanced stage of disease, so chemo radiation therapy was advised.

Table 7: Distribution as per management.

\begin{tabular}{|lll|}
\hline Management & No. of cases & Percentage \\
\hline $\begin{array}{l}\text { Wertheim's hysterectomy } \\
\text { Adjuvant radiotherapy }\end{array}$ & 03 & 30.95 \\
\hline $\begin{array}{l}\text { Chemo radiation therapy } \\
\text { advised }\end{array}$ & 29 & 07.14 \\
\hline $\begin{array}{l}\text { Chemo radiation therapy } \\
\text { received }\end{array}$ & 17 & 69.04 \\
\hline $\begin{array}{l}\text { Chemo radiation therapy } \\
\text { not received }\end{array}$ & 08 & 40.47 \\
\hline Lost to follow up & 04 & 19.04 \\
\hline
\end{tabular}

Out of these $29(69.04 \%), 17(40.47 \%)$ received chemo radiation therapy while $08(19.04 \%)$ did not take therapy and $04(09.52 \%)$ were lost to follow up. Hence their treatment details were not available (Table 7).

Out of 13 Wertheim's hysterectomies, 08 (61.535) Wertheim's were done by transperitoneal approach while remaining $05(38.46 \%)$ were done by extraperitoneal approach (Table 8).

Table 8: Distribution as per technique of Wertheim's hysterectomy.

\begin{tabular}{lll} 
Technique & Cases & Percentage \\
Transperitoneal approach & 08 & 61.53 \\
\hline Extraperitoneal approach & 05 & 38.46 \\
\hline Total & 13 & 100 \\
\hline
\end{tabular}

Out of 13 cases, obturator lymph nodes were positive in 03 cases. Amongst these three, 02 had positive internal and external iliac lymph nodes also. All these cases received postoperative radiotherapy. Common iliac lymph nodes were negative in all cases. Para-aortic lymph nodes were sampled in one suspicious case, but they were negative (Table 9).

Table 9: Distribution as per histopathological report of lymph nodes.

\begin{tabular}{|llll|}
\hline Lymph nodes & $\begin{array}{l}\text { Cases } \\
(\mathbf{n}=13)\end{array}$ & $\begin{array}{l}\text { Positive } \\
\text { Nodes }\end{array}$ & $\begin{array}{l}\text { Negative } \\
\text { Nodes }\end{array}$ \\
\hline Obturator & 08 & 03 & 05 \\
\hline Internal iliac & 07 & 02 & 05 \\
\hline External iliac & 09 & 02 & 07 \\
\hline Common iliac & 08 & 00 & 08 \\
\hline Para-aortic & 01 & 00 & 01 \\
\hline
\end{tabular}

\section{DISCUSSION}

Studies conducted by Paul SB et al, Shantla S et al, Spartacus RK et al and Devi $S$ et al reported that maximum number of cervical cancer cases were from the age group 41-50 years followed by the age group 51-60 years. $^{6-9}$

The findings of the above studies are comparable with the findings of present study. In the present study, maximum numbers of cases were in the age group 41-50 years followed by in the age group 61-70 years. The mean age of the cervical cancer case was 55.54 years and median age was 57.54 years.

The studies by Narayanswami $\mathrm{N}$ et al, Wadhvani R et al, Kaverappa et al and Devi $\mathrm{S}$ et al reported that the commonest presenting symptom was per vaginal bleeding, may be either post coital, inter menstrual or postmenopausal. ${ }^{9-12}$ The next common presenting symptom was excessive white PV discharge and foul smelling discharge. These results are comparable with the present study. 
The studies of Wadhavani $\mathrm{R}$ et al, Kaverappa et al and Singh $\mathrm{R}$ et al reported that maximum cases belong to advanced stage (IIB, III and IV) of disease. ${ }^{11-13}$ In the present study also, two third were having advanced stage at the time of diagnosis. So, study results are comparable.

The studies carried out by Akhthar PS et al, Narayanswamy $\mathrm{N}$ et al, Wadhvani R et al, Ameen NS et al and Singh $\mathrm{R}$ et al in different settings reported that squamous cell type of carcinoma was most prevalent. ${ }^{10,11,13-15}$ Above results are comparable with the present study. The studies of Rajarao P et al, Ameen NS et al and Singh $\mathrm{R}$ et al and reported that most were treated by chemo radiation therapy. ${ }^{13,15,16}$ Similar findings were noted in the present study. So, the results are comparable.

The incidence of lymph node metastasis is directly correlated with the stage of the disease. Lymph node metastasis, pelvic and/or para-aortic have a major negative impact on the survival of the patient. ${ }^{17,18}$

\section{CONCLUSION}

A high proportion of patients presented in stages III and IV. This emphasizes the need for early detection of gynecological cancers in our population. Accordingly, the importance of detection of the pre-clinical stage of the diseases by effective screening measures needs to be emphasized. Early detection predicts better prognosis. The most effective ways of preventing and controlling cervical cancer are regular cervical cancer screening above the age of 30 years. The focus should be on addressing the underprivileged women.

There are severe constraints concerning organized mass scale screening in India. These could be overcome through health education of masses, training of health professionals and changing the health seeking behaviour of women.

Cervical cancer is a favorable site for an effective control programme with its ease to access and a long latent period of intraepithelial neoplasia which is easily recognizable by the Pap smear. Thus, there is a need for initiation of community screening and educational programs through awareness campaigns.

The combined approach i.e. education, primary prevention (vaccination) and secondary prevention (screening and treatment) can be applied to cancer cervix. Health administration should plan and organize suitable programmes to impart health education for improving the awareness regarding cervical cancer. HPV vaccine immunization can be started as pilot project.

\section{Funding: No funding sources} Conflict of interest: None declared

Ethical approval: The study was approved by the Institutional Ethics Committee

\section{REFERENCES}

1. Willis RA. Definition of neoplasia. Available at http://pathology.med.sumdu.edu.ua/images/stories/le cture11_t umores_1.pdf. Accessed on 12 January 2015

2. Senapathy JG, Umadevi P, Kannika PS. The present scenario of cervical cancer control and HPV epidemiology in India: an outline. Asian Pac J Cancer Prev. 2011 Jan 1;12(5):11.

3. WHO Cancer Fact Sheet $\mathrm{N}^{\circ} 297$. Available at http://www.who.int/mediacentre/factsheets/fs297/en/ Accessed on 1 March 2015.

4. Aswathy S, Quereshi MA, Kurian B, Leelamoni K. Cervical cancer screening: Current knowledge andpractice among women in a rural population of Kerala, India. Indian J Med Res. 2012;136:205-210.

5. Denny L. Cervical Cancer treatment in Africa. Curr Opin Oncol. 2011;23(5):469-474.

6. Paul SB, Tiwary BK, Choudhury AP. Studies on the Epidemiology of Cervical Cancer in Southern Assam. Assam Univ J Sci Tech. 2011 Apr 6;7(1):3642.

7. Shanthala S, Agadi BS, Kulkarni BB, Gai PB. Snap shot of epidemiological pattern of cervical cancer patients reporting to a tertiary cancer care center in North Karnataka, India. Int $\mathbf{J}$ Adva Biol Res. 2014;4(2):178-183.

8. Spartacus RK, Paliwal R, Gaur P, Mutha S, Bhatt Pr, Malavat A. A profile of cervical cancer cases in a government medical college hospital. IOSR-JDMS. 2015;14(10):37-42.

9. Yumkhaibam SD, Ramalingam M, Singh IY, Singh TT, Singh LJ, Daru HK et al. Clinicoepidemiological study of cervical carcinoma in Northeast India. Indian J Appl Res. 2016;6(8):64-66.

10. Swamy MN, Gomathy E, Patil S, Seema BR. The scenario of cervical cancer in a rural Medical College Hospital. Int J Pharmaceu Biomed Res. 2012;3(1):14

11. Wadhwani R, Bamnia R, Meena M. Clinicopathological analysis of cancer cervix in tertiary care centre. J Evol Med Den Sci. 2013 Sep 30;2(39):7381-85.

12. Kaverappa VB, Prakash B, Kulkarni P, Renuka M. Socio-demographic profile of patients with cervical cancer in a tertiary-care cancer hospital in Mysuru, Karnataka. Int J Med Sci Public Health. 2015;4:1187-90.

13. Singh R, Shetty N, Naveed M, Pawar SB, Iska S, Alugubelli NR. Retrospective analysis of patients with carcinoma cervix in a rural/semi-urban setting in Western India. Indian $\mathrm{J}$ Med Pediatr Oncol. 2016;37:25-7.

14. Akhtar PS, Hossain MM, Masud ZM, Ruksana N, Nahar S, Nahar L, et al. A comparative study of result of treatment of cancer cervix patients treated by two separate schedules of radiotherapy. Bangladesh J Obstet Gynecol. 2010;25(2):50-58. 
15. Ameen NS, Helmi ZR. The characteristics women with cervical cancer referred for radiotherapy and /or chemotherapy. Iraqi Postgraduate Med J. 2013;12(3):321-8.

16. Rajarao P, Hemanth Kumar B. Study of socio demographic profile of cancer cervix patients in tertiary care hospital, Karimnagar. Int J Biol Med Res. 2012;3(4):2306-10.

17. Berman ML, Keys H, Creasman W, DiSaia P, Bundy B, Blessing J. Survival and pattern of recurrence in cervical cancer metastatic to periaortic lymph nodes (a GOG study). Gynecol Oncol. 1984;19(1):8-16.
18. Stehman FB, Bundy BN, Dsaia PJ, Keys HM, Larson JE, Flower WC. Carcinoma of the cervix treated with radiation therapy: a multivariate analysis of prognostic variables in the gynecologic oncology group. Cancer. 1991;67(11):2776-85.

Cite this article as: Umate $P$, Thengal DS, Kurdukar D. Study of clinical profile of cervical cancer patients: a hospital based study. Int J Reprod Contracept Obstet Gynecol 2017;6:4873-8. 